\title{
Research of a Biomass Boiler with Stirling Engine Microgeneration Unit
}

\author{
Jānis KRAMENS ${ }^{1 *}$, Edgars VĪGANTS ${ }^{2}$, Ivars LIEPIN̦Š ${ }^{3}$, Linards VĒRNIEKS ${ }^{4}$, \\ Viktorija TERJANIKA ${ }^{5}$
}

${ }^{1-5}$ Institute of Energy systems and Environment, Riga Technical University, Azenes st. 12/1, Riga, Latvia

\begin{abstract}
A number of intergovernmental agreements, the most important of which are the Paris Agreement (UN Framework Convention on Climate Change) and the European Green Deal, provide for resource efficiency and the reduction of greenhouse gas and particulate matter (PM $\left.2.5, \mathbf{P M}_{10}\right)$ emissions to 2030 (short-term program to reduce emissions by at least $55 \%)$ and to achieve emissions-neutral production, transport and household activities by 2050. The European Union (EU) has taken the lead in developing and implementing climate change mitigation policies for both industrial and private residential homes in the world through a green course. As an EU country, Latvia has joined both the EU-level climate policy and developed its policy, regulatory documents and action plans for 2021-2030 (Latvia's National Energy and Climate Plan for 2021-2030), climate policy, including a policy aimed at significantly reducing GHG emissions and increasing efficiency in the household sector. Achieving these climate policy goals requires both a change in human habits and more efficient technologies. This article discusses one of the technological solutions that can reduce both greenhouse gas emissions and the release of $P M_{2.5}$ and $P M_{10}$ from individual heating systems in private homes and small commercial facilities. Calculations of electrical energy production in mCHP mode of the system for household self-consumption based on experiments will be done. The technology involves the production of heat from biomass or other types of renewable energy sources while generating electricity for self-consumption. Conclusions of CHP mode on overall efficiency will be done.
\end{abstract}

Keywords - Climate policy; cogeneration; efficiency; emissions

\begin{tabular}{|ll}
\hline $\mathrm{kWh}_{\mathrm{th}}$ & Kilowatt Hours of Thermal Energy \\
$\mathrm{Wh}_{\mathrm{el}}$ & Watt Hours of Electricity \\
$\mathrm{mCHP}$ & Micro Cogeneration \\
$\mathrm{UN}$ & United Nations \\
$\mathrm{GHG}$ & Greenhouse Gases \\
$\mathrm{EU}$ & European Union \\
$\mathrm{RES}$ & Renewable Energy Resources \\
$\mathrm{DH}$ & District Heating \\
$\mathrm{SE}$ & Stirling Engine \\
$\mathrm{NET}$ & Neto Energy Balance Calculating System \\
\hline
\end{tabular}

* Corresponding author.

E-mail address: radtehcentrs@yahoo.com 


\section{INTRODUCTION}

Latvia is on its way to achieve the EU climate neutrality goals - by $205040 \%$ of the energy produced from renewable energy sources (RES) from total energy consumption (EU average goal for 2030 is $20 \%$ ). A significant part of the energy produced by RES is wood biomass (in $201862.6 \mathrm{PJ}$ or $80.4 \%$ of the total RES consumption). Energy production from biomass, although less than from fossil energy sources, causes greenhouse gas (GHG) emissions. The main consumers of wood biomass are households (mostly apartment buildings) who using district heating $(\mathrm{DH})$ net and households that are not connected to district heating (mostly private houses). If DH is characterized by an efficient heat production process, then the use of wood biomass in private houses is generally inefficient and has high emissions. The main sources of $\mathrm{PM}_{2.5}$ emissions in 2016 are the households and service sector $(58.8 \%)$, which widely use biomass combustion plants, the energy production sector $(13.2 \%)$ with the extensive use of biomass in district heating boiler houses and cogeneration plants, fuel combustion in the industrial sector $(12.5 \%)$ and in the transport sector $(4.7 \%)$ [1].

The situation in the household sector is even worse with lower installed power in comparison with industrial sector with the production of electricity in micro-generation plants for their own consumption. In the interests of consumers, Article 30 of the Electricity Market Law has introduced a net electricity billing system for microgenerators, and it has been in force since 1 January 2014 for all households that produce electricity for their own needs from RES. In the middle of 2019, the NET system was used by 384 household consumers and their total installed capacity was 2.12 MW. Since 2012, the Ministry of Economics has issued approximately 600 permits for the introduction of new electricity generation facilities, most of which are microgeneration facilities with a capacity of $0.0035 \mathrm{MW}$ to $0.01 \mathrm{MW}$. This amount is very small and in a year 2019, 550 microgenerator connections (up to $11.1 \mathrm{kWh}$ ) were registered, with total installed electrical capacity $3.23 \mathrm{MW}$, which is a small part $(\sim 0.1 \%)$ of the total installed electrical capacity in Latvia [2].

Latvian government has chosen the main directions for action to reduce emissions in the household sector in 2020-2030:

- Informing and educating the society about the role of RES and the role of each individual in climate change;

- Connection to district heating networks in dense heat consumption areas;

- Development of non-emission RES technologies - solar collectors and PV panels, heat pumps.

To achieve the goals of the EU green course, it will not be enough just to introduce nonemission technologies and transform the industrial sector, it will be important to develop all directions of the economy, including efficient use of RES biomass in the private house sector for heating and electricity production. Especially in countries such as Latvia where forests cover more than $50 \%$ of Latvia's territory, although on average $\sim 25 \%$ of the contribution of economic sectors is made up of wood industry and 10-13 million $\mathrm{m}^{3}$ of wood is felled every year, the growth of wood stock in the forest is still much faster than in economic activity. In 2018, 20824 tons of wood biomass was produced, of which almost $3 / 4$ was exported in the form of energy or cellulose chips and pellets. This amount of wood biomass could be used in the local market and create products with higher added value.

Households consume energy in the form of heat and electricity. There are a total of 817900 households in Latvia, of which $31.5 \%$ are located in rural areas and $68.5 \%$ in urban areas. $82.5 \%$ of the rural population is provided with decentralized heat supply in sparsely populated rural areas and most of the heat produced by the $\mathrm{DH}$ is used in cities $(74.3 \%$ of the number of urban households). The total number of households providing individual heat 
supply is 356600 , including in rural areas 212429 indicating that most likely these households in rural areas are private houses (total number of private houses 211 118) [3].

The condition of private house heating equipment is often assessed as very poor, most of it consists of heating equipment (boilers, stoves) that are powered by firewood and are at least 25 years old. Only a small part is high efficiency equipment (e.g., wood gasification boilers). Most of the equipment is old and its efficiency is lower than $60 \%$, which is also evidenced by the primary heat consumption in the country, of which $\mathrm{DH}$ accounts for $26 \%$ and individual heat supply $74 \%$, although $56.4 \%$ of households are connected to DH.

In more than $90 \%$ of cases, firewood heating is used for private house heating, but it is not only inefficient but also has significant dew emissions. The table below clearly shows the difference of $\mathrm{CO}_{2}$ emissions between the last years, which proves the development of the described situation with technologies in each of the sectors:

TABLE 1. GHG CO 2 EMISSIONS FROM DH AND HOUSEHOLDS

\begin{tabular}{lll}
\hline $\mathrm{CO}_{2}$ emitter & $\mathrm{CO}_{2}$ emissions in 2010, $\mathrm{t}$ & $\mathrm{CO}_{2}$ emissions in 2017, $\mathrm{t}$ \\
\hline $\mathrm{DH}$ & 2277.27 & 1540.54 \\
Households & 1805.37 & 2049.06 \\
\hline
\end{tabular}

Even more significant are particulate emissions in the household sector, which have an adverse effect on human health. Particulate matter emissions from older heating systems are up to 180 times higher at certain heating modes than newer generation heating systems. If households started to replace obsolete individual heating equipment in rural areas with modern wood gasification plant with integrated electricity microgeneration equipment, it would contribute to Latvia's goals in using RES resources and achieving climate neutrality by 2050 , as well as promote rural development and population health.

\section{TECHNOLOGY DESCRIPTION}

At present, the supply of advanced small and micro scale biomass-based mCHP equipment is limited and not available on free market - only at the laboratory concept or prototype level. A study of available mCHP technologies concludes that only gaseous or liquid fossil fuelfired plants are commercially available.

One of the technologies powered by solid biomass fuel is the Stirling engine-based mCHP system. Stirling engines are external combustion engines which, in combination with an electric generator and a boiler, form a closed micro-cogeneration system.

Stirling engine-based micro-cogeneration units have several advantages:

- Wide choice of fuel to be used in the combustion process;

- High thermodynamic efficiency;

- Low noise level;

- Relatively long maintenance interval [4].

Stirling engines have a higher fuel to energy generation ratio, so this type of equipment is more suitable for larger dwellings with a higher heat load to meet heat and electricity demand at the same time.

\subsection{Working Principles of Stirling Engine}

The Stirling engine itself has been known since 1816, but the technology for mCHP is still under development. It has good potential in terms of its ability to achieve high efficiency, 
fuel flexibility, low emissions and good performance at part load, unlike internal combustion engines.

The supply of heat energy from external sources allows the use of a wide range of fuels. For example, renewable energy sources such as solar or biomass. Stirling engines have low service and maintenance rates, are quieter and smoother than internal combustion engines [5].

A free-piston Stirling engine (FPSE) is a variant of Stirling engine in which the displacer and power piston are not interlinked by any mechanical crank mechanism. Flexure springs attached to the respective displacer and power piston cyclically stores and releases mechanical energy, analogously to the angular momentum stored in the flywheel of a kinematic Stirling engine. The displacer and power piston resonate in a shared natural frequency, deriving power from an oscillatory pressure variation that exists mainly due to the cyclic heating and cooling of a gaseous working substance [6], schematically shown in Fig. 1.

The Stirling engine mCHP system can be the main power supply in the household, in combination with other home appliances, like solar panels and solar batteries. The possibility of supplying external heat energy allows constant control of the fuel energy source.

Stirling engines are simple in design and, compared to internal combustion engines, do not require a cylinder lubrication process, an ignition system and an intake/exhaust valve system. Those characteristics as mentioned before are crucial if the engines are used in heating systems that have to run continuously throughout the heating season, or, even in some cases, continuously throughout the year. Low vibration and noise levels allow these devices to be placed in residential homes or even in the living spaces themselves. The above characteristics indicate that Stirling engine-based mCHP can be used in households, especially in rural areas, where it is not possible to connect to the $\mathrm{DH}$ and solid biomass fuel (firewood) is available locally.

A single-cylinder, free-piston engine that meets the above requirements for maintenance and ease of operation by our consideration to be the most suitable of the Stirling engine types for household use, as shown in Fig. 1 [7].

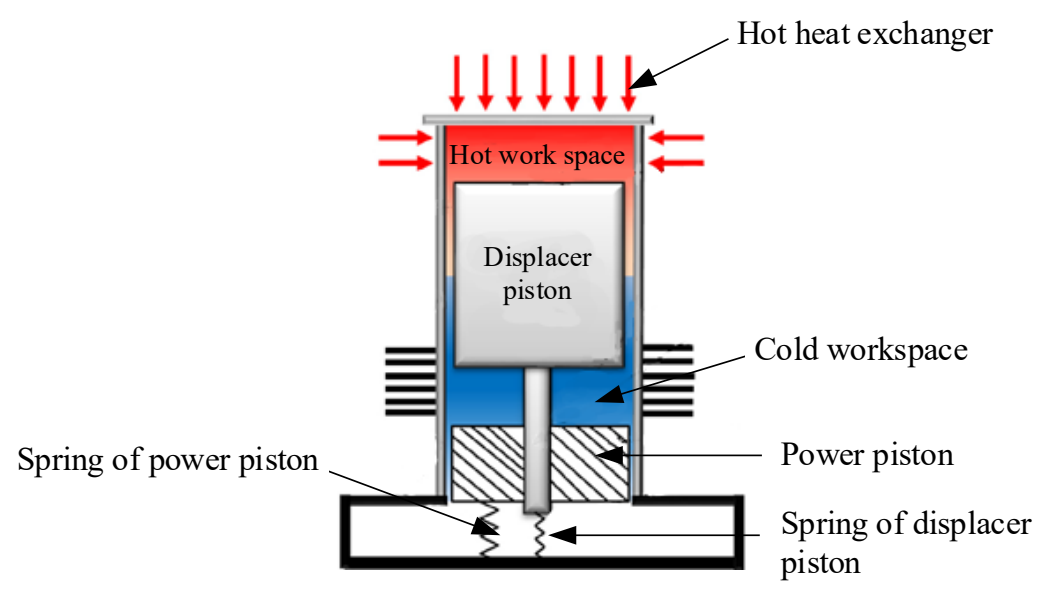

Fig. 1. Schematic of free piston Stirling engine [7]. 
Such motors are still not manufactured on an industrial scale, but their design features allow its integration with a power generator in one shell. The single-shell design facilitates integration in to a biomass boiler, creating a household $\mathrm{mCHP}$ unit.

\section{TASks OF The Experimental Part}

Experimental test unit was developed and set up to evaluate the application of households self-consumption scale Stirling engine-based mCHP (Fig. 2). Following experimental tasks was set up by researcher group(authors):

1. Assess the impact of the cogeneration regime on the total heat production of the biomass boiler heating installation;

2. To determine the quality of fuel combustion of a heating installation by measuring $\mathrm{CO}_{2}$ and $\mathrm{O}_{2}$ emissions in flue gases at the beginning, middle and end of the operation cycle;

3. To determine the changes in the productivity of the Stirling engine mCHP system depending on the firewood quality, moisture level, the amount and fraction of fuel loaded in the boiler furnace;

4. To determine the gasification and combustion chamber temperatures at the stable operation of the system in cogeneration mode.

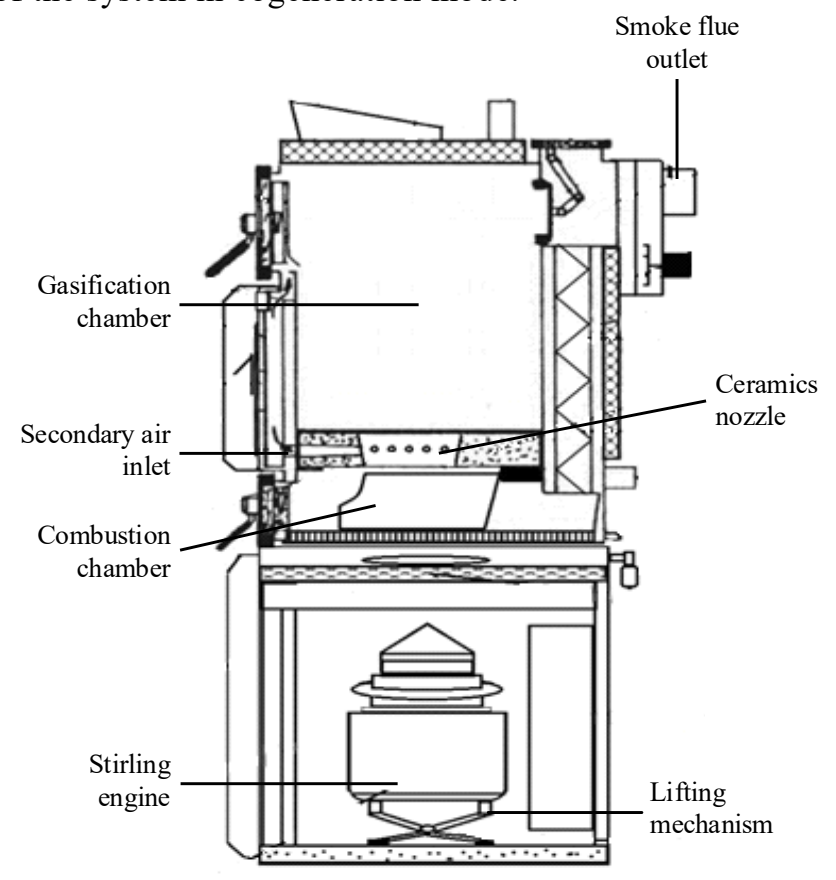

Fig. 2. Schematic representation of the experimental equipment with the lifting mechanism.

In the experiment, a model system containing a conventional solid biomass wood log heating boiler with $31 \mathrm{kWh}$ nominal thermal power [8], with upper gasification and lover combustion chambers (Fig. 3) and Microgen Free Piston Stirling Engine [9] with integrated electric generator (Fig. 4) nominal power of $1050 \mathrm{~kW}$ was used. 
TABLE 2. BOILER WORKING MODE AND ENERGY INPUT

\begin{tabular}{|c|c|c|c|}
\hline $\begin{array}{l}\text { Exp. } \\
\text { No. }\end{array}$ & Boiler mode & Fuel & $\begin{array}{l}\text { Energy Input with } \\
\text { fuel, } \mathrm{kWh}\end{array}$ \\
\hline 1. & Heating & Wood logs with $20 \%$ moisture & 39.40 \\
\hline 2. & Heating & Wood logs with $20 \%$ moisture & 55.16 \\
\hline 3. & Heating & Wood logs with $20 \%$ moisture & 39.40 \\
\hline 4. & CHP & Wood logs with $20 \%$ moisture & 65.01 \\
\hline 5. & $\mathrm{CHP}$ & Wood logs with $25 \%$ moisture & 59.17 \\
\hline 6. & CHP & Wood logs with $16 \%$ moisture & 83.06 \\
\hline 7. & CHP & Wood logs with $17 \%$ moisture & 96.67 \\
\hline 8. & CHP & $\begin{array}{l}\text { Wood logs with } 12 \% \text { moisture }(50 \%) \text {, } \\
\text { saw dust bulks with } 8 \% \text { moisture }(50 \%)\end{array}$ & 266.69 \\
\hline 9. & $\mathrm{CHP}$ & Wood logs with $10 \%$ moisture & 118.07 \\
\hline
\end{tabular}

Note: Fuel moisture was measured manually with Moisture Meter mentioned in Section 3.1, contend during experiments

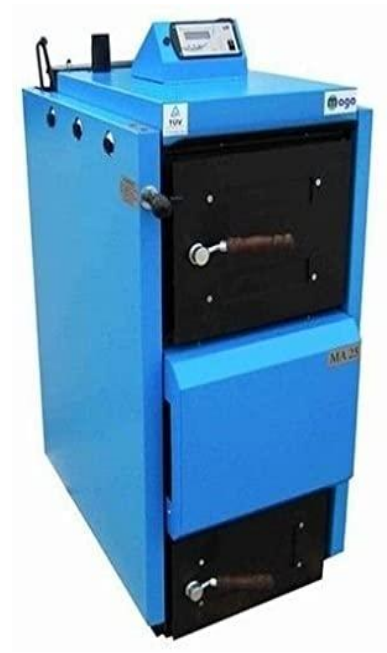

Fig. 3. Solid biomass gasification boiler [8]. 


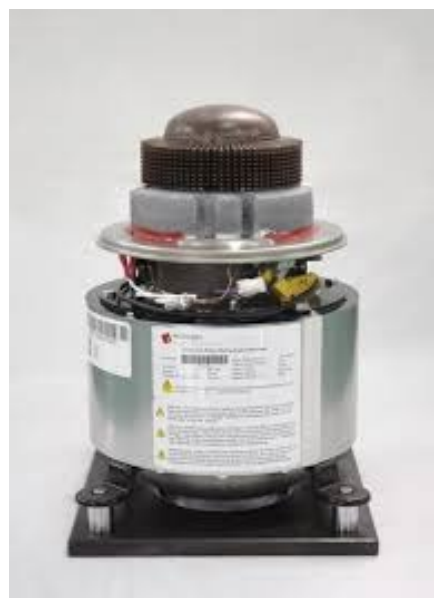

Fig. 4. Microgen Stirling engine with integrated electric generator [9].

To perform the experiments, an engine lifting mechanism was developed for the unit (Fig. 2). Lifting mechanism ensures that the engine head is fed into the combustion chamber so that the unit works in cogeneration mode also if lowered, allowing the boiler to operate only in heat production mode.

In order to perform the experiments, the equipment was installed in the municipal DH boiler house. Schematics Fig. 5. The DH boiler house was chosen to provide a constant heat demand. This study does not analyse the operation of the system in a real Latvian household and does not consider the impact of household consumption indicators on the operation of the system.

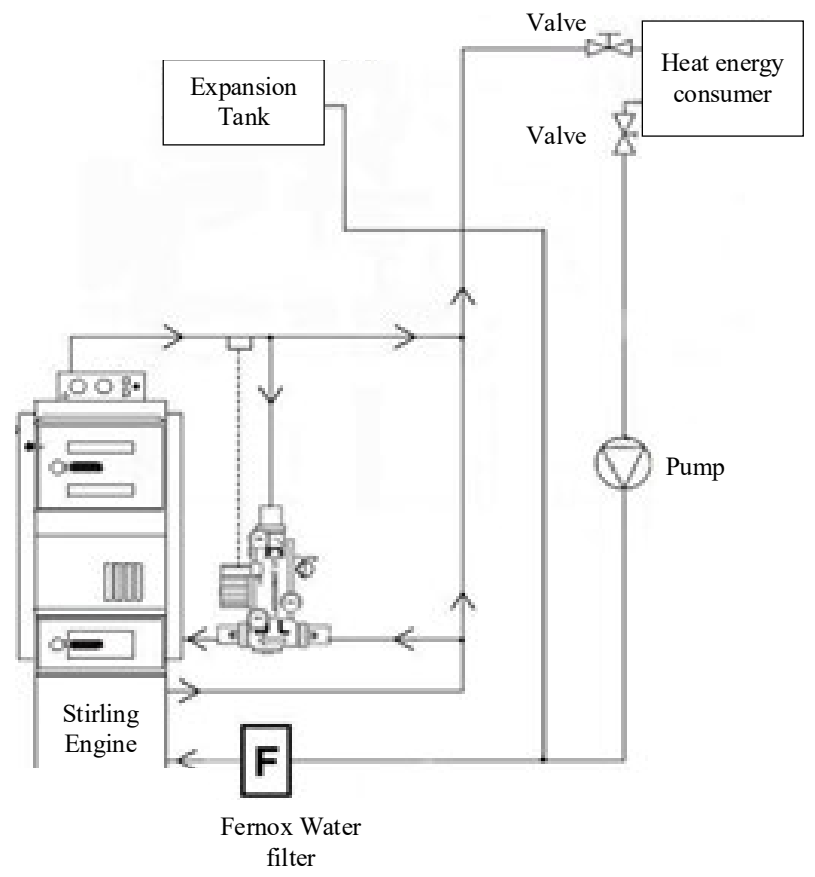

Fig. 5. Drawing of the connection of experimental mCHP equipment with the Heat energy consumer. 


\subsection{Analytical Equipment Used for Experiments}

The following equipment was used for the experiments:

- Flue gas analyser Testo 340;

- Data acquisition software with temperature sensors Stirling Engine Data viewer;

- IR Thermal camera InfrecAnalyzer LT;

- Heat meter Sontex Supercal 739;

- Wood moisture analyser iCcraft.

\section{Results}

1. Different fuel moisture and entered mass of firewood was used to detect boiler thermal and summary CHP mode efficiency. To detect cogeneration mode effect to boiler thermal efficiency experiments are performed in thermal and CHP mode using fuel with the same parameters, as described Table 2. Three experiments (1-3, Table 2) were performed only in the heat energy production mode, while the experiments (4-9) were performed in the cogeneration mode.

The calculations of thermal and electrical efficiency were done in each of the experiment. Comparison between input energy (firewood) and measured output of thermal and electrical energy was performed. Results of the experiments are presented in Fig. 6, showing how much energy was entered with fuel (wood) and how much thermal and electrical energy was produced in each of the experiment expressed in $\mathrm{kWh}$. efficiency (\%), as well as electricity production is present in each of experimental cases. In addition, it was calculated how much in average thermal and electrical energy experimental unit is able to produce from $1 \mathrm{~kg}$ of wood.

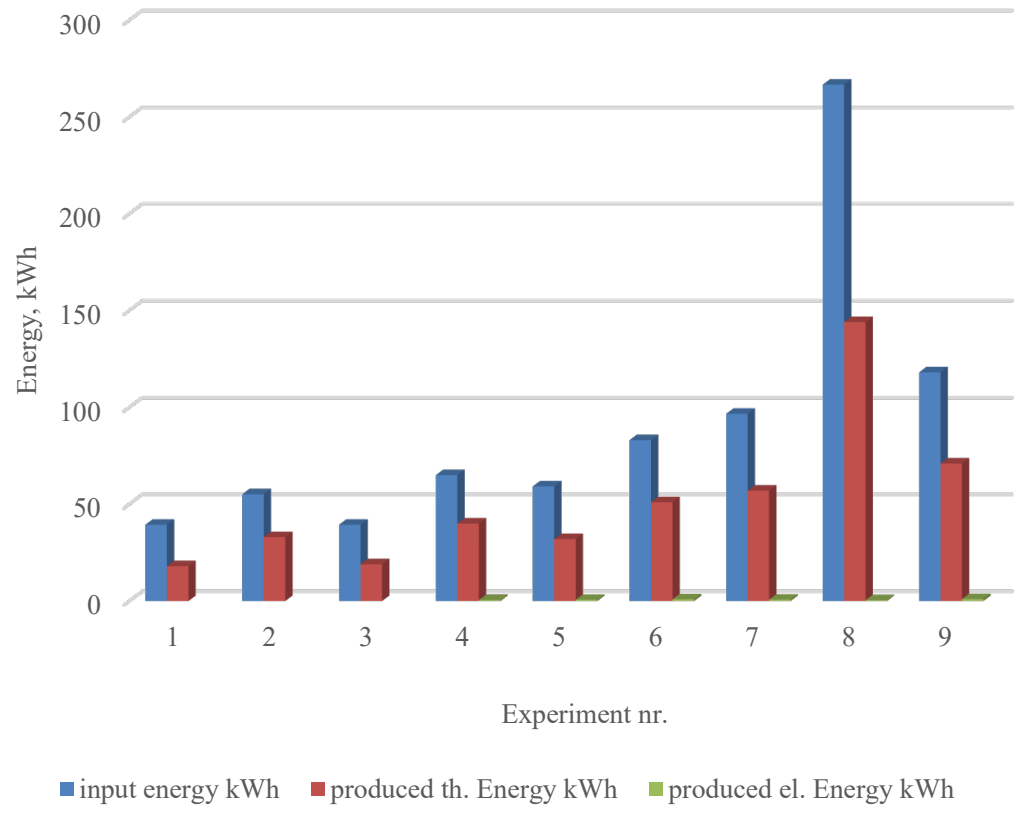

Fig. 6. Produced thermal and electrical energy from input energy. 
From experiment results presented on Fig. 6, calculations of system thermal and summary (thermal + electrical) efficiency expressed in (\%) were calculated Fig. 7.

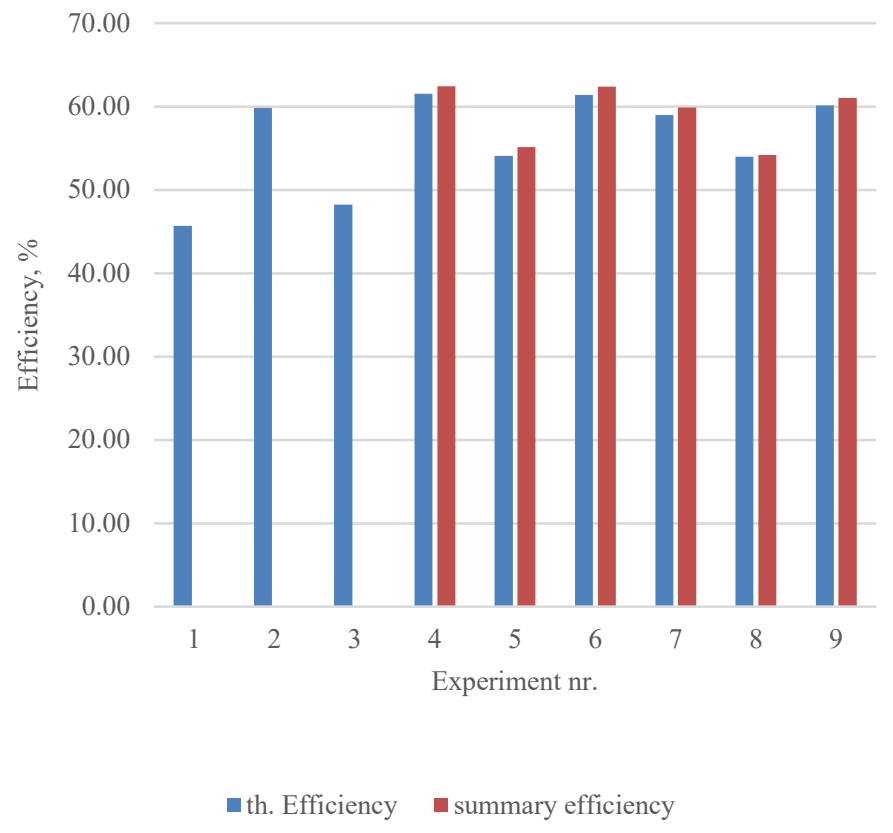

Fig. 7. Thermal and summary CHP mode efficiency.

Evaluating the results of the experiments (Table 2), no influence of electricity production in CHP mode was found to the thermal productivity of the boiler Fig. 8. Those findings could be possible because of specific construction of the boiler, because part of the heat energy was recovered from Stirling engine cooling circuit, so it gives extra heat collecting surface. Those electricity production figures (Fig. 6) include boiler self-consumption, which is about $180 \mathrm{~W}$ [8]. No markable loss of thermal capacity was found in experiments $4-9$. The above leads to the conclusion that the operation of the plant in the cogeneration mode increases the overall efficiency of the plant (Fig. 7) compared to the identical boilers [10], [11], which operate only in the heat energy production mode.

Evaluating the emissions from the heating system Fig. 5, measurements of $\mathrm{CO}_{2}$ and $\mathrm{O}_{2}$ in flue gases were taken every 15 min during all experiment with flue gas analyser Testo 340 . Emission measurements were performed as described in methodology [13]. Qualitative combustion process was observed, in stable combustion process from 30-180 min. of the experiment Fig. 8, which complies with the 'A' class boiler standards [12]. 


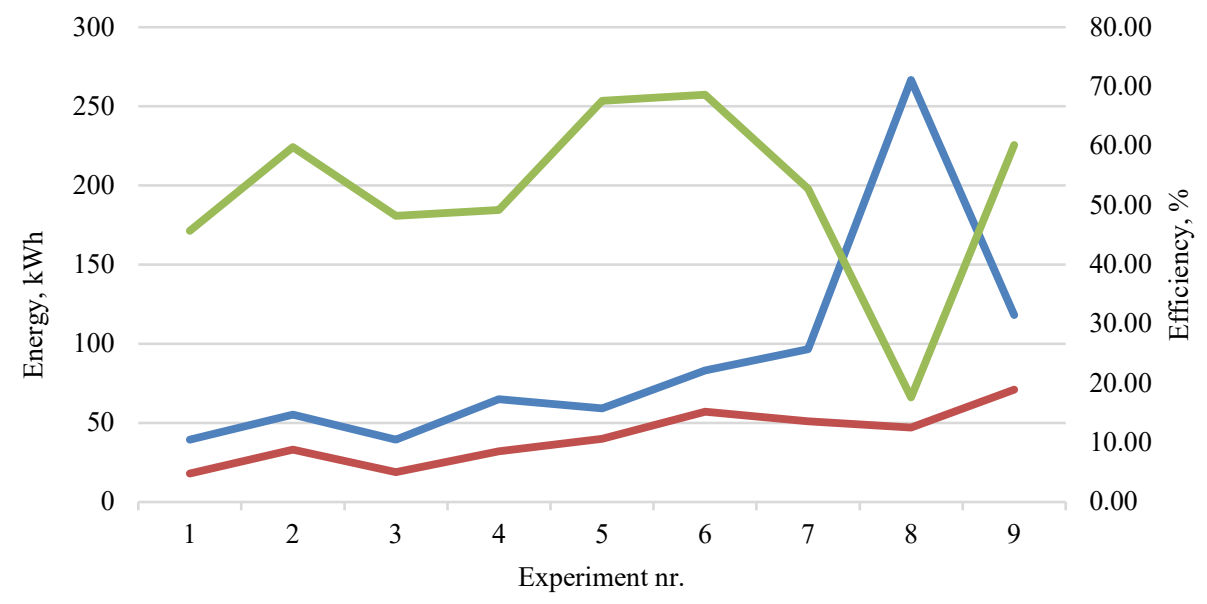

Input Energy, kWh —Ouput Th. Energy, kWh —Thermal Eefficiency, \%

Fig. 8. Thermal efficiency of the boiler.

2. The productivity of the Stirling engine was measured with Stirling Engine Data Viewer software, by logging data every $15 \mathrm{~min}$. According to the plan set (Table 2), different types of fuel and moisture content were used in the experiments. Additionally, firewood and sawdust briquette combinations were tested.

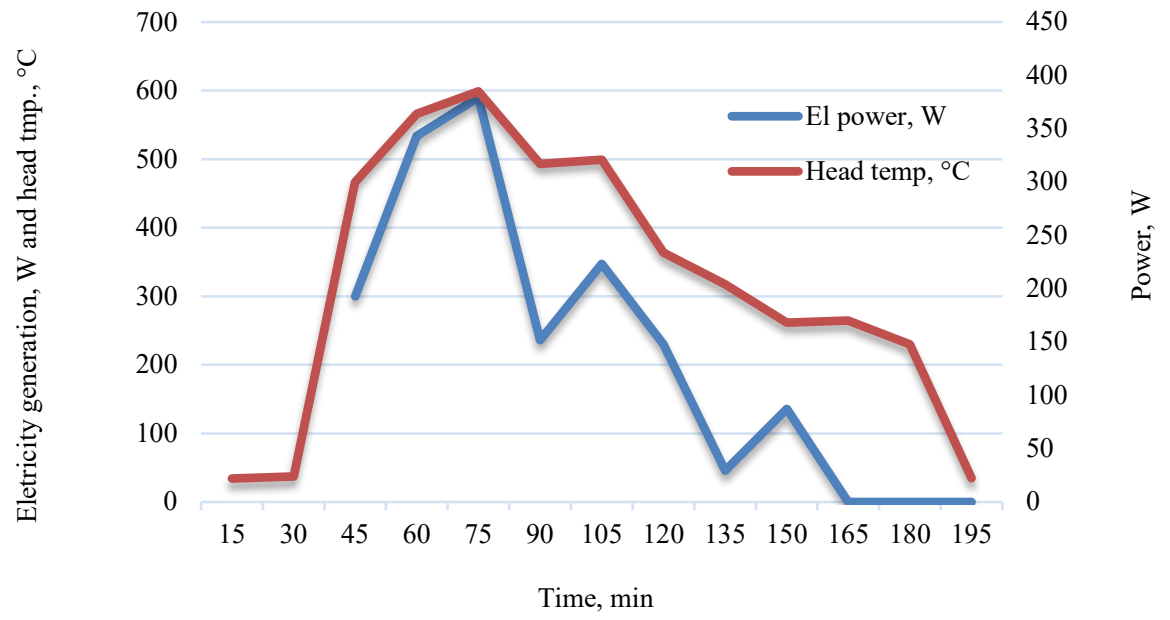

Fig. 9. The power of the mCHP electric generator (blue line), depending on the Stirling engine head temperature (red line) from the most representative experiment No. 7.

In the course of the experiment, a correlation was found between the temperature of the Stirling engine head and the electricity produced by the generator in each of the experiments 4-9 (Fig. 6). One of the most representative experiment results are shown in Fig. 9 on experimental minutes 90 and 150 . We also found out that electricity production drops down 
sharply with relatively smooth temperature drop and then rises up with a little temperature increase. Measurements were taken 13 times, every 15 minutes, fuel was injected only before the boiler was ignited and was not replenished during the experiment, which explains the nature of the slowly dropping temperature curve. The operation of the mCHP device was monitored with analytical equipment and software as used in [14].

3. In order to determine the temperature of the boiler in the stable cogeneration mode during the experiment, temperature measurements were performed by IR Thermal camera Infrec Analyzer LT.
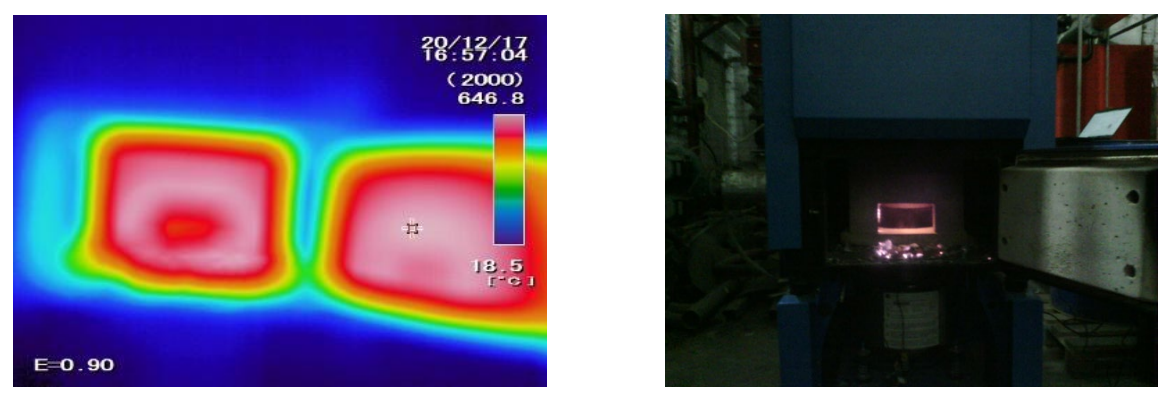

Fig. 10. Combustion chamber thermograph and photo images

When measuring the temperature of the combustion chamber with a thermal camera, a direct correlation was found between the temperature of the combustion chamber and the electric power generated by the engine. The best result of the experiment (in the $5^{\text {th }}$ measurement episode of experiment 7) was $590 \mathrm{~W}_{\text {el }}$, excluding the self-consumption of the equipment (estimated to vary from 70 to $150 \mathrm{~W}$ depending on the operating mode of the equipment), at a combustion chamber temperature of around $600{ }^{\circ} \mathrm{C}$, (Fig. 10) and drove the head temperature $385^{\circ} \mathrm{C}$, captured from Data Viewer Software according to [15].

\section{Discussions}

Our research was based on comparison of the literature observation and the data obtained in the practical part of the experiments.

We conclude that it is possible to achieve a higher electrical power for the experimental equipment. Based on the information found in the literature review, the temperature of the combustion chamber in which the Stirling engine head can be inserted is up to $800-900{ }^{\circ} \mathrm{C}$ [7]. Considering what has been proved in the experimental part of the study, Fig. 9 measurement shows temperature around $600{ }^{\circ} \mathrm{C}$ only, so it can be predicted that the maximum electric power of a particular Stirling engine together with a solid biomass boiler can reach 800-900 W. As described on boiler specification [13] combustion chamber temperature can be reached up to $1200{ }^{\circ} \mathrm{C}$. The observations made in the experimental part of the study indicate that the maximum engine power could also be increased by varying the boiler max coolant temperatures as well as engine cooling system inlet/outlet temperatures. Using higher calorific fuel, such as very dry, less than $10 \%$ moisture, or very dense wood like oak firewood would increase temperature in boiler combust. According to the results of the experimental part, the relative amount of emissions to the produced heat and electricity is lower in comparison with analogous boilers without micro-cogeneration, while " $\mathrm{A}$ " class 
boilers [9] are certified with the same level of emissions just for heat production only, but with the same amount of emissions we have produced electricity as shown in Fig. 8.

\section{Conclusions}

Solid-biomass micro-cogeneration units based on the Stirling engine can be more efficient by part of produced electricity than similar heating units operating only in the heat production mode. From measurements in experimental part of the research based on data expressed on data shown on Fig. 6, we calculated that in average from $1 \mathrm{~kg}$ of wood could be produced $2.23 \mathrm{kWh}$ thermal energy and in addition we get $7.84 \mathrm{Wh}$ of electrical energy. The tests dose not showed markable heat energy production difference when unit was working in thermal or CHP mode.

To capture precise efficiency increase more detailed experimental equipment should be designed with options to measure full thermal balance of the system.

Gaseous emissions ware measured during number of experiments, we captured that during stable operation mode, using wood with moisture content less than $15 \% \mathrm{O}_{2}$ content in exhaust gases was in a range $4-5 \%$, using woods logs with moisture $20 \%$ and more, $\mathrm{O}_{2}$ content increase above $10 \%$, what we conclude is low quality combustion process. During experiments $\mathrm{CO}_{2}$ emission differences between unit working in thermal or CHP mode was not captured.

Electrical energy production from Stirling engine alternator was tightly depending on engine head temperature (Fig. 9). We conclude that to get more precise data of produced electrical energy longer experiments are necessary, while during start and finish phase of the combustion process heat temperature is variating and it gives not full overview of the electricity generating process. Our longest experiment was $235 \mathrm{~min}$. only.

Overall, we conclude that using Stirling engine based mCHP system in households gives GHG emission savings by part of extra produced electrical energy compare to conventional wood $\log$ gasification boilers.

\section{ACKNOWLEDGEMENTS}

I would like to thank RTU VASSI laboratory for the opportunity to use measuring equipment for the practical part of the research. Special thanks to SIA Balteneco for the opportunity to conduct research in its own boiler house, using its infrastructure. Also, thanks to Microgen LTD for the opportunity to use a micro-cogeneration unit for research and Dainis Seržants for responsiveness and quality work by connecting the research unit to the boiler house infrastructure.

\section{REFERENCES}

[1] Ministry of Environmental Protection and Regional Development Republic of Latvia. Latvijas Gaisu Piesārṇojošo Vielu Emisiju Esošās Situācijas Izpēte, Emisiju Aprēḳinu Veikšana Valsts Gaisa Piesārṇojuma Samazināšanas Rīcības Plāna 2020.-2030. Gadam Izstrādei (Existing Latvian air pollutants emissions situation research, emissions calculation reduction for the development of an action plan for 2020-2030). Riga: VARAM, 2018. (in Latvian)

[2] Cabinet of Ministers. Par Latvijas Nacionālo energètikas un klimata plānu 2021.-2030. gadam (On the Latvian National Energy and Climate Plan 2021-2030 year). Latvijas Vēstnesis 2020:29. (in Latvian)

[3] Central Statistical Bureau Republic of Latvia. Energy consumption in households. Environment and Energy databases [Online]. [Accessed 8.03.2021]. Available: http://data1.csb.gov.lv/pxweb/en/vide/vide_energetika_energ_pat/

[4] Padinger R., et al. Best practise report on decentralized biomass fired CHP plants and status of biomass fired smalland micro scale CHP technologies. IEA Bioenergy, 2019.

[5] Sheykhia M., et al. Performance investigation of a combined heat and power system with internal and external combustion engines. Energy Conversion and Management 2019:185:291-303.

https://doi.org/10.1016/j.enconman.2019.01.116 
[6] Abuelyamen A., Ben-Mansour R. Energy efficiency comparison of Stirling engine types ( $\alpha, \beta$, and $\gamma$ ) using detailed CFD modelling. International Journal of Thermal Sciences 2018:132:411-423. https://doi.org/10.1016/j.ijthermalsci.2018.06.026

[7] Smirnov S. V., et al. A calculation method of a heat rejection system in a lunar power plant consisting of a free-piston Stirling engine (FPSE). Acta Astronautica 2021:180:46-57. https://doi.org/10.1016/j.actaastro.2020.12.008

[8] MAGA. Wood-gasifying boilers MA [Online]. [Accessed 10.03.2021]. Available: https://magasro.sk/en/wood-andbrickets-boilers-d/wood-gasifying-boiler

[9] Microgen Engine. Microgen's compact gas fired Heater-Generator [Online]. [Accessed 15.05.2018]. http://stirlingtech.com/wp-content/uploads/2018/05/ThermoGen1.0kW.pdf

[10] Thomas J., et al. Measurement of the in-situ performance of solid biomass boilers. Report number: 30663-P3-2. Cheltenham: KIWA, 2018.

[11] Priedniece V., et al. Biomass Co-firing Laboratory Equipment. Energy Procedia 2017:113:390-395. https://doi.org/10.1016/j.egypro.2017.04.019

[12] WoodCo Energy Ireland. E-Compact Prestige 25P/40P. Installation and Operation Manual. Donaskeigh: WoodCo Energy Ireland, 2017.

[13] Zhu S., et al. Modelling and experimental investigation of a free-piston Stirling engine-based micro-combined heat and power system. Applied Energy 2018:226:522-533. https://doi.org/10.1016/j.apenergy.2018.05.122

[14] Priedniece V., et al. Laboratory research of the flue gas condenser - fog unit. Energy Procedia 2018:147:482-487. https://doi.org/10.1016/j.egypro.2018.07.056

[15] Kazulis V., et al. Biomass and natural gas co-firing - evaluation of GHG emissions. Energy Procedia 2018:147:558 565. https://doi.org/10.1016/j.egypro.2018.07.071 